\title{
How Submerged Macrophyte Restoration Promotes a Shift of Phytoplankton Community in a Shallow Subtropical Lake
}

\author{
Lei Zeng', ${ }^{1,}$ Feng He${ }^{1}$, Yi Zhang ${ }^{1}$, Biyun Liu ${ }^{1}$, Zhigang Dai ${ }^{1}$, \\ Qiaohong Zhou ${ }^{1 *}$, Zhenbin Wu ${ }^{1}$ \\ ${ }^{1}$ State Key Laboratory of Freshwater Ecology and Biotechnology, Institute of Hydrobiology, \\ University of the Chinese Academy of Sciences, Wuhan 430072, China \\ ${ }^{2}$ University of Chinese Academy of Sciences, Beijing 100049, China
}

Received: 20 October 2016

Accepted: 2 January 2017

\begin{abstract}
Submerged macrophyte restoration has been widely used to decrease phytoplankton and combat eutrophication in many temperate shallow lakes. However, very limited studies have been done to explore its potential in decreasing phytoplankton in subtropical shallow lakes. We hypothesize that macrophyte restoration can also decrease phytoplankton and shift community structures in subtropical shallow lakes. In order to test our hypothesis, we consistently investigated submerged macrophytes, nutrients, and phytoplankton for three years in a shallow subtropical lake. Multiple analytical methods were employed to assess the effect of macrophyte restoration on the phytoplankton community. The results showed that the density and biomass of total phytoplankton after restoration were less compared to those before the restoration. During the restoration, species diversity significantly increased every year, but the change in species richness was not significant. Moreover, phytoplankton community structure also transformed greatly. Especially cyanobacteria density gradually decreased until almost disappeared; Chlorophyta density also significantly decreased from $4.6 \times 10^{6}$ cell/L to $1.9 \times 10^{6}$ cell/L. Although changes in the densities of other groups were not significant, their ratios in total phytoplankton significantly increased. The changes in four dominant species were also significant during the restoration, with Microcystis aeruginosa, $M$. incerta, and Chlamydomonas sp. significantly decreasing, but Chlorella pyrenoidosa significantly increasing. Correlation analysis between phytoplankton and environmental factors (macrophyte and water quality) showed that macrophytes were negatively correlated with total phytoplankton, TN, and COD, but total phytoplankton was positively correlated with $\mathrm{TN}$ and COD. These relations indicated that macrophyte restoration might not only directly inhibit phytoplankton growth, but also indirectly decrease phytoplankton by both bottom-up and top-down controls of phytoplankton. Therefore, these results basically proved our hypothesis, and more attention should be focused on this method in future lake management.
\end{abstract}

Keywords: cyanobacteria blooms, chlorophyta, nutrient, allelopathy, West Lake

*e-mail: qhzhou@ihb.ac.cn 


\section{Introduction}

Eutrophication has caused the disappearance of diverse submerged macrophytes, a loss of biodiversity, and regime shifts of aquatic ecosystems in lakes all over the world [1-4]. Cyanobacteria blooms, the widely known environmental disaster caused by eutrophication in freshwater lakes, are annoying because of their threat to human health and aquatic organism survival [5-6]. In China, such blooms frequently occur in freshwater ecosystems when nutrition loading exceeds a certain threshold. For example, the outbreak of cyanobacteria blooms in Lake Taihu in 2007 greatly damaged aquatic ecosystem services, seriously affecting the lives of nearby residents and causing major economic losses [7].

In order to mitigate the negative impacts of eutrophication, both physico-chemical and biological methods have been used in many lake restoration projects [8-10]. Among them, cutting off external nutrient loads flowing into the lake is usually considered a prerequisite for lake restoration [11], but usually does not immediately reduce the nutrition concentration in the water column. Because the chemical or biological within-lake resilience can delay the decline rate of nutrient loading and hinder the process of the formation of clear water [12]. Therefore, several biological restoration methods (e.g., removal of fish to control phytoplankton, macrophyte transplantation and protection, introduction of mussels) were widely studied to strengthen the restoration and overcome the delays [13-16]. Among the above methods, submerged macrophyte restoration has been widely applied in temperate lake management as submerged macrophytes are important for maintaining clear water in shallow lakes [17]. And their restoration and reconstruction play important roles in lowering nutrients, suppressing phytoplankton biomass, and developing water transparency $[12,18]$. Some studies conducted in temperate lakes found that submerged macrophytes can reduce phytoplankton biomass, and then make a regime shift from a turbid state dominated by phytoplankton to a clear state dominated by macrophytes in shallow lakes [19-21].

However, compared with the detailed studies in temperate lakes, research about the effects of macrophyte restoration on the phytoplankton community are limited in subtropical and tropical lakes. The role of submerged macrophytes in the phytoplankton community is not clear in these lakes [22-23]. For example, Bachmann et al. [24] found that no significant correlations exist between the abundance of submerged macrophyte and phytoplankton biomas in a set of lakes in southern Florida in the United States. Moreover, studies in the Mediterranean and subtropical South American lakes, in contrast, found a significant negative relationship between submerged macrophyte and phytoplankton biomass [2527]. Therefore, more studies and field experiments should be conducted to explore the interactions between macrophyte and phytoplankton communities in subtropical/tropical lakes.

Table 1. Pearson's correlation analysis of environmental factors and phytoplankton community parameters during macrophyte restoration in Maojiabu Lake $(\mathrm{N}=27)$. Abbreviations of these factors and parameters: $\mathrm{MB}$, macrophyte biomass; MC, macrophyte coverage; COD, chemical oxygen demand; TP, total phosphorus; $\mathrm{TN}$, total nitrogen; $\mathrm{NH}_{4}^{+}$, ammonia nitrogen; $\mathrm{NO}_{3}^{-}$, nitrate nitrogen; $\mathrm{PD}$, phytoplankton density; $\mathrm{SR}$, species richness; $\mathrm{CD}$, cyanobacteria density; $\mathrm{ChD}$, chlorophyta density.

\begin{tabular}{|c|c|c|c|c|c|c|c|c|c|c|c|c|c|c|}
\hline & PD & Chl-a & SR & Diversity & $\mathrm{CD}$ & $\mathrm{ChD}$ & $\mathrm{MC}$ & MB & COD & $\mathrm{TP}$ & $\mathrm{TN}$ & $\mathrm{NH}_{4}^{+}$ & $\mathrm{NO}_{3}^{-}$ & $\begin{array}{l}\text { TN/ } \\
\text { TP }\end{array}$ \\
\hline PD & 1 & & & & & & & & & & & & & \\
\hline Chl-a & $0.9 * *$ & 1 & & & & & & & & & & & & \\
\hline Richnes & 0.31 & 0.22 & 1 & & & & & & & & & & & \\
\hline Diversity & 0.17 & -0.06 & 0.35 & 1 & & & & & & & & & & \\
\hline CyD & $0.92 * *$ & $0.8^{* *}$ & 0.31 & 0.19 & 1 & & & & & & & & & \\
\hline $\mathrm{ChD}$ & $0.64 * *$ & $0.7 * *$ & -0.01 & -0.18 & 0.35 & 1 & & & & & & & & \\
\hline $\mathrm{MC}$ & $-0.62 * *$ & $-0.68 * *$ & 0.12 & 0.19 & $-0.54 * *$ & $-0.6^{* *}$ & 1 & & & & & & & \\
\hline $\mathrm{MB}$ & $-0.53 * *$ & $-0.66^{* *}$ & 0.23 & $0.43 *$ & $-0.5 * *$ & $-0.57 * *$ & $0.87 * *$ & 1 & & & & & & \\
\hline COD & $0.48^{*}$ & $0.64 * *$ & -0.21 & -0.35 & $0.54 * *$ & 0.24 & $-0.57 * *$ & $-0.69 * *$ & 1 & & & & & \\
\hline $\mathrm{TP}$ & 0.19 & 0.08 & 0.07 & 0.36 & -0.06 & 0.36 & -0.16 & 0.09 & -0.15 & 1 & & & & \\
\hline $\mathrm{TN}$ & $0.46^{*}$ & $0.6^{* *}$ & -0.23 & -0.31 & 0.26 & $0.81 * *$ & $-0.78 * *$ & $-0.77 * *$ & $0.43 *$ & 0.19 & 1 & & & \\
\hline $\mathrm{NH}_{4}^{+}$ & 0.33 & 0.21 & 0.12 & -0.23 & 0.33 & 0.19 & -0.34 & -0.35 & 0.15 & -0.3 & 0.36 & 1 & & \\
\hline $\mathrm{NO}_{3}^{-}$ & 0.23 & $0.38 *$ & -0.38 & $-0.44 *$ & 0.02 & $0.75^{* *}$ & $-0.54 * *$ & $-0.63 * *$ & 0.28 & 0.11 & $0.9^{* *}$ & 0.38 & 1 & \\
\hline TN/TP & -0.07 & 0.09 & -0.14 & $-0.6^{* *}$ & 0.03 & 0.07 & -0.18 & $-0.39 *$ & 0.19 & $-0.77 * *$ & 0.31 & $0.58 * *$ & 0.38 & 1 \\
\hline
\end{tabular}

In Bold: $* P<0.05, * * P<0.01$ 


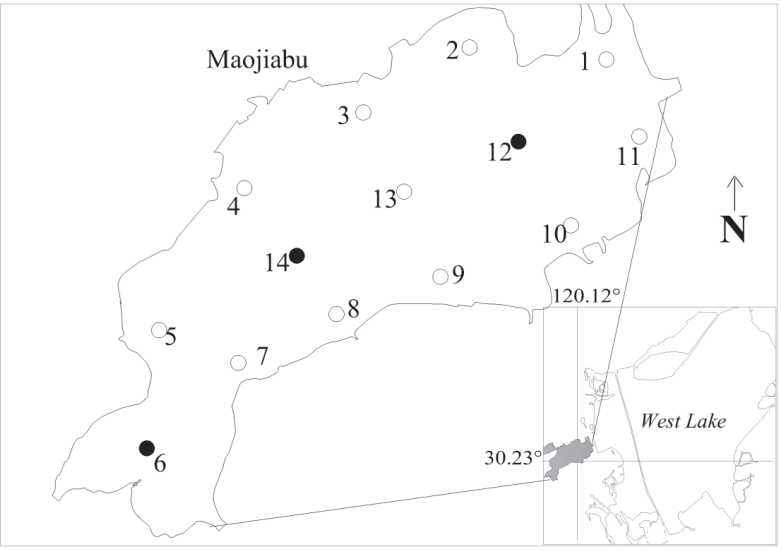

Fig. 1. The location and enlarged view of Maojiabu Lake in West Lake. The 14 sites for submerged macrophyte and three blackfilled circles for phytoplankton and water quality parameters were surveyed from 2010 to 2012.

For this paper, we hypothesise that reconstructed macrophytes can also decrease phytoplankton and shift the community structure in subtropical, shallow lakes, and thus we have performed a full investigation on submerged macrophytes, nutrients, and phytoplankton during a macrophyte restoration over a period of three years. Our goal was to evaluate the role of macrophyte restoration in decreasing phytoplankton, and explore the possible mechanisms causing changes in the phytoplankton community in a shallow, subtropical lake.

\section{Materials and Methods}

\section{Study Site}

West Lake $\left(30^{\circ} 15^{\prime} \mathrm{N}, 120^{\circ} 09^{\prime} \mathrm{E}\right)$, with an area of $6.5 \mathrm{~km}^{2}$, a mean depth of $2.27 \mathrm{~m}$, and a water volume of $1.4 \times 10^{7} \mathrm{~m}^{3}$, is a typical shallow lake located west of Hangzhou in Zhejiang province, China. This lake is subject to a subtropical monsoon climate, and surrounded by the eastern Hangzhou downtown and the western small hills. Since the 1950s, the outbreak of algae blooms and ecosystem degradation caused by huge exogenous nutrients often occurred in West Lake [28]. Thus, the industrial or domestic wastewater into West Lake was cut off by lake managers many years ago, and the release of endogenous nutrition and exogenous sources (such as the effluent of rivulets, atmospheric precipitation, and runoff), are the main sources of water nutrient in West Lake.

As one of the most famous lakes in China, West Lake was officially added to the World Heritage List from 2011 because of its beautiful natural landscape and profound historical and cultural heritage. Many tourists from all over the world are attracted to Hangzhou every year, creating huge economic benefits. Accordingly, the Hangzhou government invests a lot of manpower and financial sources every year to protect the West
Lake aquatic environment, especially with respect to eutrophication. Numerous methods, including sediment dredging about once every decade, water transfer, etc., have been employed to improve the lake's ecosystem. Although these measures could alleviate eutrophication and increase transparency in the water column to a certain extent, they have a very limited role in strengthening biological control and stabilizing the sediment. Thus, the lake manager also has put forward some other methods to further improve the aquatic ecosystem. As one of these methods, submerged macrophyte restoration was adopted to reconstruct the macrophyte community and improve the aquatic ecosystem in some sub-lakes.

This study was performed in Maojiabu Lake, which has an area of $0.27 \mathrm{~km}^{2}$ and a mean depth of $1.3 \mathrm{~m}$ and is located west of West Lake (Fig. 1). This area was formerly a farmland, but was excavated artificially in 2003 to expand the basin area of West Lake. Before 2010, this lake was almost in a turbid state with low transparency and a high Chlorophyll a (Chl- $a$ ) concentration, and almost no submerged macrophytes were distributed in the lake.

\section{Submerged Macrophyte Restoration}

To restore the lake ecosystem, an attempt was made to reestablish the submerged macrophyte community from November in 2010, and turions of Potamogeton crispus (about $500 \mathrm{~kg}$ ) were planted in most parts of the lakes (ca. $80 \%$ overall area). Next February, seeds of Vallisneria spiralis (about $300 \mathrm{~kg}$ ) were planted in zones shallower than $0.5 \mathrm{~m}$. One month later, about 10 tons of adult macrophytes ( $V$. spiralis, Ceratophyllum demersum, and Myriophyllum verticillatum) were transplanted into zones deeper than $0.5 \mathrm{~m}$, except for some area in the lake center. However, $V$. spiralis in the zones shallower than $0.5 \mathrm{~m}$ unfortunately grew poorly from March to October 2011. Thus macrophyte reestablishment was performed again in the shallow zones in November 2011. This time, about 3 tons of adult $V$. spiralis instead of their seed were planted in the shallow zones, and macrophyte restoration finally achieved success in 2012.

\section{Sampling and Treatment}

During the restoration, tracking surveys on submerged macrophytes were conducted in spring (April), summer (July), and autumn (October) from 2010 to 2012. Fourteen sample sites distributed evenly within the lake were selected to measure the biomass and macrophyte coverage (Fig. 1). At each sampling site, macrophytes were collected in triplicate by a grass sickle with a sample of $0.18 \mathrm{~m}^{2}$. Macrophyte fresh weight was obtained after washing by tap water and being weighed by a PuChun electronic scale $(6 \mathrm{~kg} / 0.2 \mathrm{~g})$ in the laboratory later, and converted to gram per square meter. Moreover, macrophyte species and coverage were also recorded in the field sampling.

Water quality was also monitored seasonally as with macrophytes, and three sampling sites $(6,12$, and 14) 

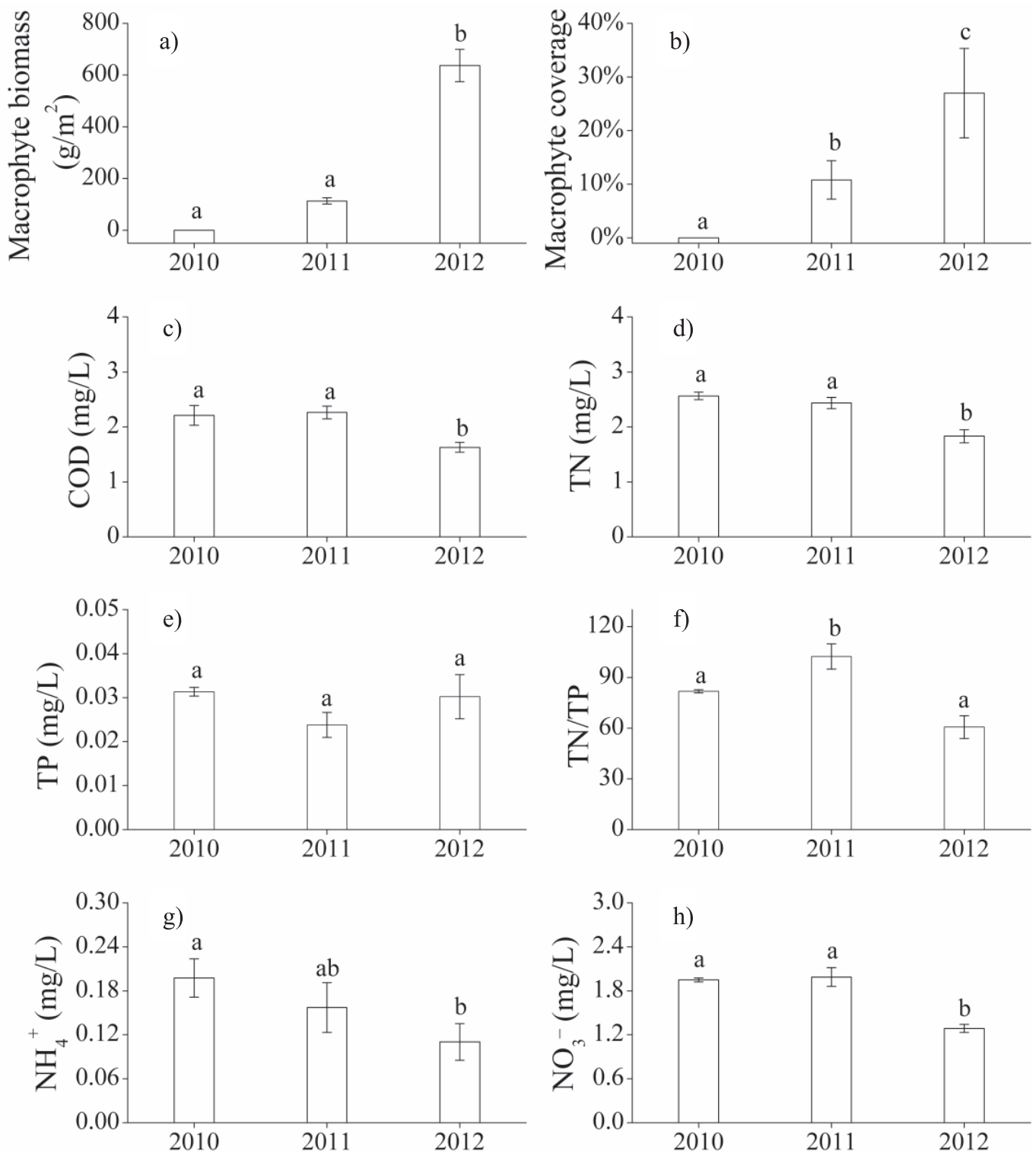

Fig. 2. Interannual mean changes $( \pm \mathrm{SE})$ in environmental factors during the restoration $(\mathrm{N}=27)$. Bars with identical lowercase letters indicate no significant differences $(P>0.05)$, while bars with different letters indicate significant differences $(P<0.05)$.

were chosen from the 14 sites for monitoring water quality (Fig. 1). The samples for water quality were obtained by collecting $1 \mathrm{~L}$ water from the $0.5 \mathrm{~m}$ depth into a $1.5-\mathrm{L}$ polyethylene pot for later hydrochemical analyses in a laboratory. Chemical oxygen demand (COD), TN, nitrate nitrogen $\left(\mathrm{NO}_{3}^{-}\right)$, ammonium nitrogen $\left(\mathrm{NH}_{4}^{+}\right), \mathrm{TP}$, and Chl-a were analyzed according to the standard methods [29].

A phytoplankton sample was also collected seasonally from 2010 to 2012 in the same sites as for water quality, and obtained by injecting $1 \mathrm{~L}$ water into a $1.5-\mathrm{L}$ polyethylene pot in triplicate in each site (Fig. 1). The sample was fixed with about $10 \mathrm{~mL}$ Lugol's iodine solution ( $2 \%$ final conc.) and sedimented for $48 \mathrm{~h}$. The supernatant in the sample was removed by a siphon, and the remaining sample was concentrated into $30 \mathrm{~mL}$. Cell density was measured by absorbing $0.1 \mathrm{~mL}$ sub-sample in a Sedgwick-Rafter counting chamber under microscope at 200-400×magnification. Phytoplankton species were identified according to Hu and Wei [30].

\section{Statistical Analyses}

Levene's test was used to assess equality of variances. The changes in the phytoplankton community, nutrients, and submerged macrophytes during the restoration were tested using ANOVA for repeated measures. Significant differences between means were determined using Duncan's honest significant difference test at a 0.05 significance level. Pearson's correlation coefficients were also used to assess the relationship between phytoplankton and environmental factors. All the analysis was conducted with SPSS 21 for Windows. Data are reported as mean \pm standard error. 

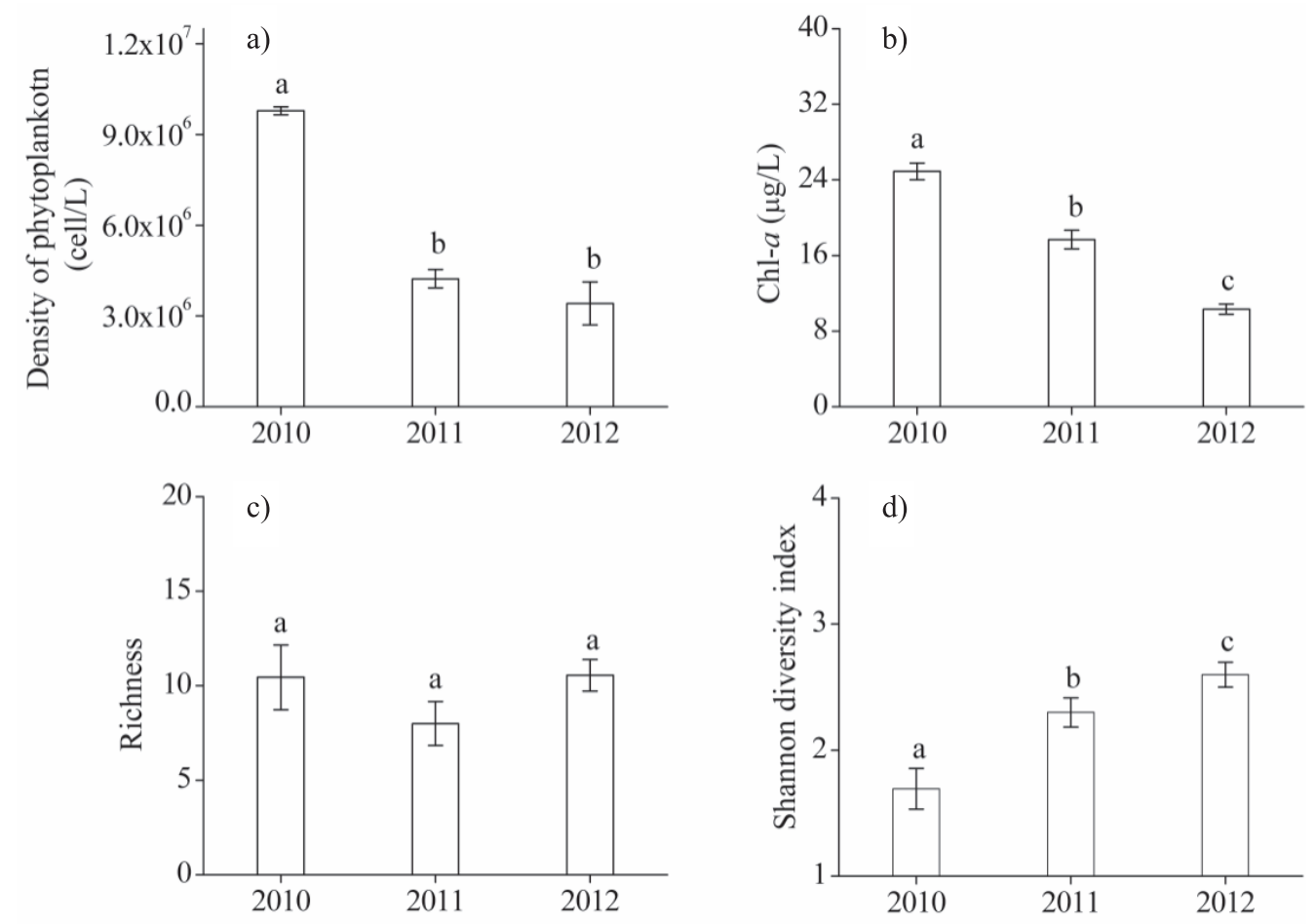

Fig. 3. Interannual mean changes ( \pm SE) in phytoplankton density a), Chl- $a$ b), species richness c), and Shannon diversity index d) during the restoration $(\mathrm{N}=27)$.

\section{Results}

\section{Interannual Variations of Environmental Factors}

Three surveys conducted in 2010 prior to macrophyte reestablishment showed that almost no submerged macrophytes were found in the lake. However, after the first restoration trial in November 2010 and February 2011, the tracking surveys in 2011 showed that annual mean biomass and coverage of macrophytes significantly increased compared to those in $2010 \quad(\mathrm{P}<0.05$, Figs $2(\mathrm{a}-\mathrm{b})$, which were $113 \pm 12 \mathrm{~g} \cdot \mathrm{m}^{-2}$ and $11 \pm 4 \%$, respectively. The dominant species ( $V$. spiralis, P. crispus, $C$. demersum, and M. Verticillatum) were mainly distributed in the deep zones. However, both the germination rate of $V$. Spiralis seeds and the survival rate of seedlings were at a very low level in the shallow zones. After the second restoration trial in the shallow zones in November 2011, the surveys conducted in 2012 exhibited that the annual mean biomass and coverage of macrophytes increased

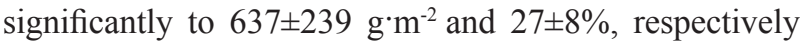
$(\mathrm{P}<0.05$, Figs $2(\mathrm{a}-\mathrm{b})$, and the dominant species were $V$. spiralis, Najas marina, and $M$. verticillatum. The $N$. marina was probably brought into the lake with other macrophytes during two restoration attempts.

The ANOVA water quality results indicated that the interannual variations of various parameters except for TP basically presented significant differences during the restoration $(P<0.05$, Figs $2(\mathrm{c}-\mathrm{h})$. The changes in $\mathrm{TN}$, $\mathrm{NO}_{3}^{-}$, and COD were especially insignificant from 2010 to 2011 until a drastic decreases in $2012(P<0.05)$. The change in $\mathrm{NH}_{4}^{+}$was only significant between 2010 and 2012, and the change in TP was insignificant during the restoration. The ratio of TN to TP significantly increased in 2011 compared to 2010, but decreased again in 2012.

\section{Interannual Variations of the Phytoplankton Community}

The surveys about phytoplankton during macrophyte restoration showed that total phytoplankton densities after two restoration trials in 2011 and 2012 significantly decreased compared to those in 2010 prior to the restoration $(P<0.05)$, but the difference between 2011 and 2012 was not significant (Fig. 3a). Total phytoplankton biomass (represented by Chl- $a$ concentration) significantly decreased yearly $(P<0.05$, Fig. $3 \mathrm{~b})$. Although the change in species richness was not significant during the restoration (Fig. 3c), Shannon diversity index significantly increased yearly $(P<0.05$, Fig. 3 d) .

In addition, phytoplankton community structure also exhibited great changes during the restoration. Cyanobacteria and chlorophyta especially dominated the phytoplankton community in 2010, and their densities were $4.1 \pm 0.5 \times 10^{6} \mathrm{cell} / \mathrm{L}$ and $4.6 \pm 0.5 \times 10^{6} \mathrm{cell} / \mathrm{L}$, occupying $42 \%$ and $47 \%$ of phytoplankton density, respectively (Figs 4(a-d). After the first trial in 2011, the density and percentage of cyanobacteria in the phytoplankton community significantly decreased to $4.6 \pm 2.7 \times 10^{5}$ cell/L and $11 \%$, respectively. Chlorophyta density also decreased to $3.2 \pm 0.5 \times 10^{6}$ cell/ $\mathrm{L}$, but the percentage significantly 

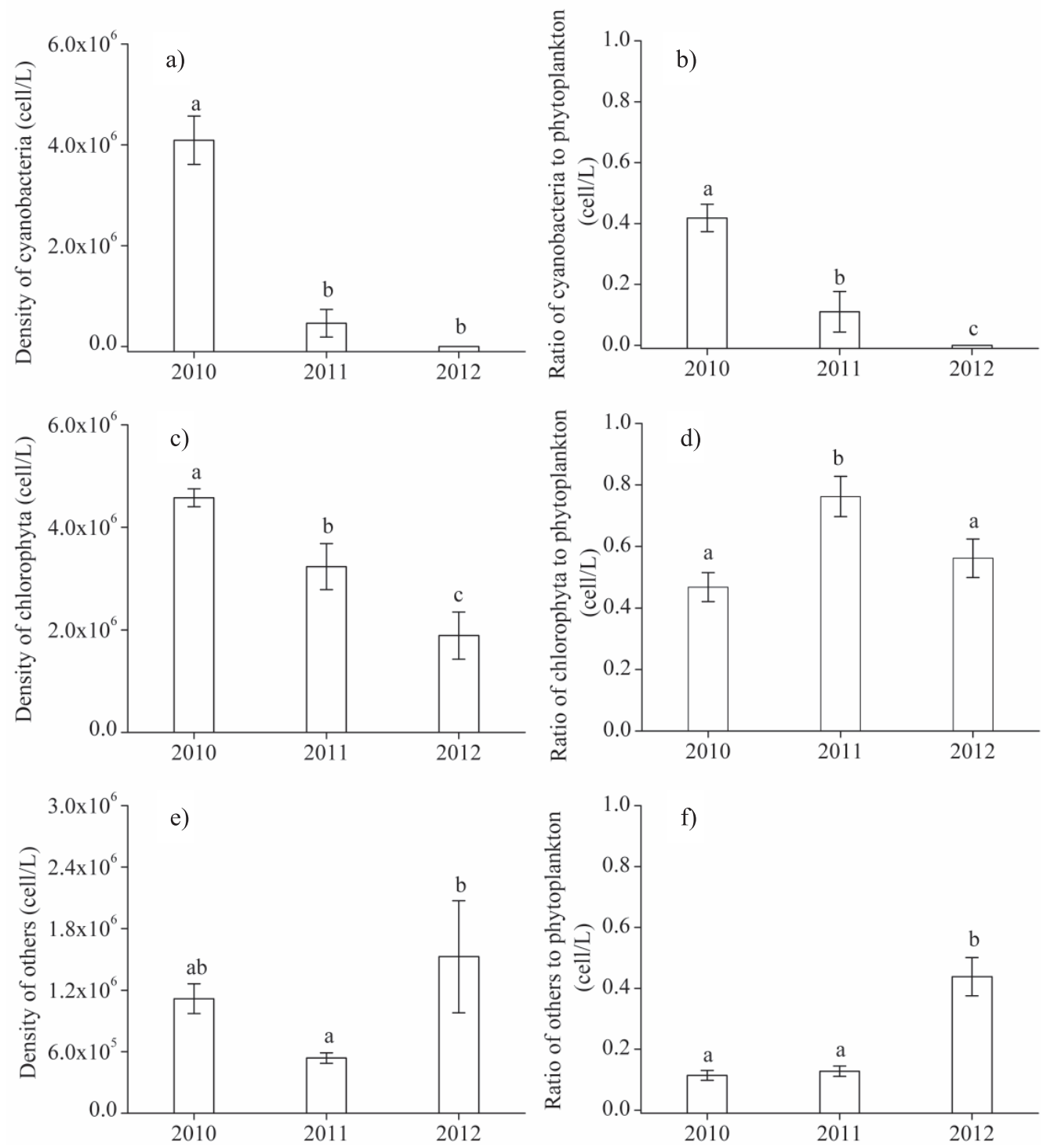

Fig. 4. Interannual changes in the densities of three groups (cyanobacteria a), chlorophyta c), and others e)) and the ratios of these groups to phytoplankton ( $\mathrm{b}, \mathrm{d}$, and $\mathrm{f})$ during the restoration $(\mathrm{N}=27)$.

increased to $77 \%$. After the second trial in 2012, however, cyanobacteria basically vanished, and the density and percentage of chlorophyta also decreased to $1.9 \pm 2.7 \times 10^{5}$ cell $/ \mathrm{L}$ and $60 \%$. Although the changes in the densities of other groups were insignificant during the restoration, and their ratios in the phytoplankton community in 2012 were greater than those in 2010 and 2011 (Figs 4(e-f)).

The interannual changes in densities of dominant species were also significant during the restoration (Fig. 5). The density of Chlamydomonas sp. significantly decreased yearly from $3.5 \pm 0.7 \times 10^{6}$ in 2010 to $1.1 \pm 0.8 \times 10^{6}$ cell/L in $2012(P<0.05 ;$ Fig. 5a). The density of Chlorella pyrenoidosa in 2012 significantly increased compared to values in 2010 and $2011(P<0.05$, Fig. 5b), but no significant difference existed between 2010 and 2011. However, Microcystis aeruginosa and $M$. incerta in 2012 significantly decreased compared to 2010 $(P<0.05$; Figs 5(c-d), and were finally at a low level or basically vanished.

\section{Correlation Analysis of Phytoplankton and Environmental Factors}

Pearson's correlation analysis of phytoplankton and environmental factors during the restoration showed that the density and biomass of total phytoplankton were positively correlated with $\mathrm{TN}\left(\mathrm{r}_{\text {density }}=0.46, P<0.05\right.$; $\left.\mathrm{r}_{\text {biomass }}=0.6, P<0.01\right)$ and $\operatorname{COD}\left(\mathrm{r}_{\text {density }}=0.48, P<0.05\right.$; $\left.\mathrm{r}_{\text {biomass }}=0.64, P<0.01\right)$, but negatively correlated with macrophyte coverage $\left(\mathrm{r}_{\text {density }}=-0.62, P<0.01 ; \mathrm{r}_{\text {biomass }}=-0.68\right.$, $P<0.01)$ and biomass $\left(\mathrm{r}_{\text {density }}=-0.53, P<0.01 ; \mathrm{r}_{\text {biomass }}=-0.66\right.$, $P<0.01$ ) (Table 1). The diversity index was positively affected by macrophyte biomass $(\mathrm{r}=0.43, P<0.05)$, but negatively correlated with TN/TP $(\mathrm{r}=-0.6, P<0.01)$. The densities of the two dominant groups (cyanobacteria and chlorophyta) had negative correlations with macrophyte coverage $\left(\mathrm{r}_{\text {cya }}=-0.54, P<0.01 ; \mathrm{r}_{\text {chl }}=-0.5, P<0.01\right)$ and biomass ( $\left.\mathrm{r}_{\text {cya }}=-0.6, P<0.01 ; \mathrm{r}_{\text {chl }}=-0.57, P<0.01\right)$, but the positive relations only occurred between cyanobacteria 

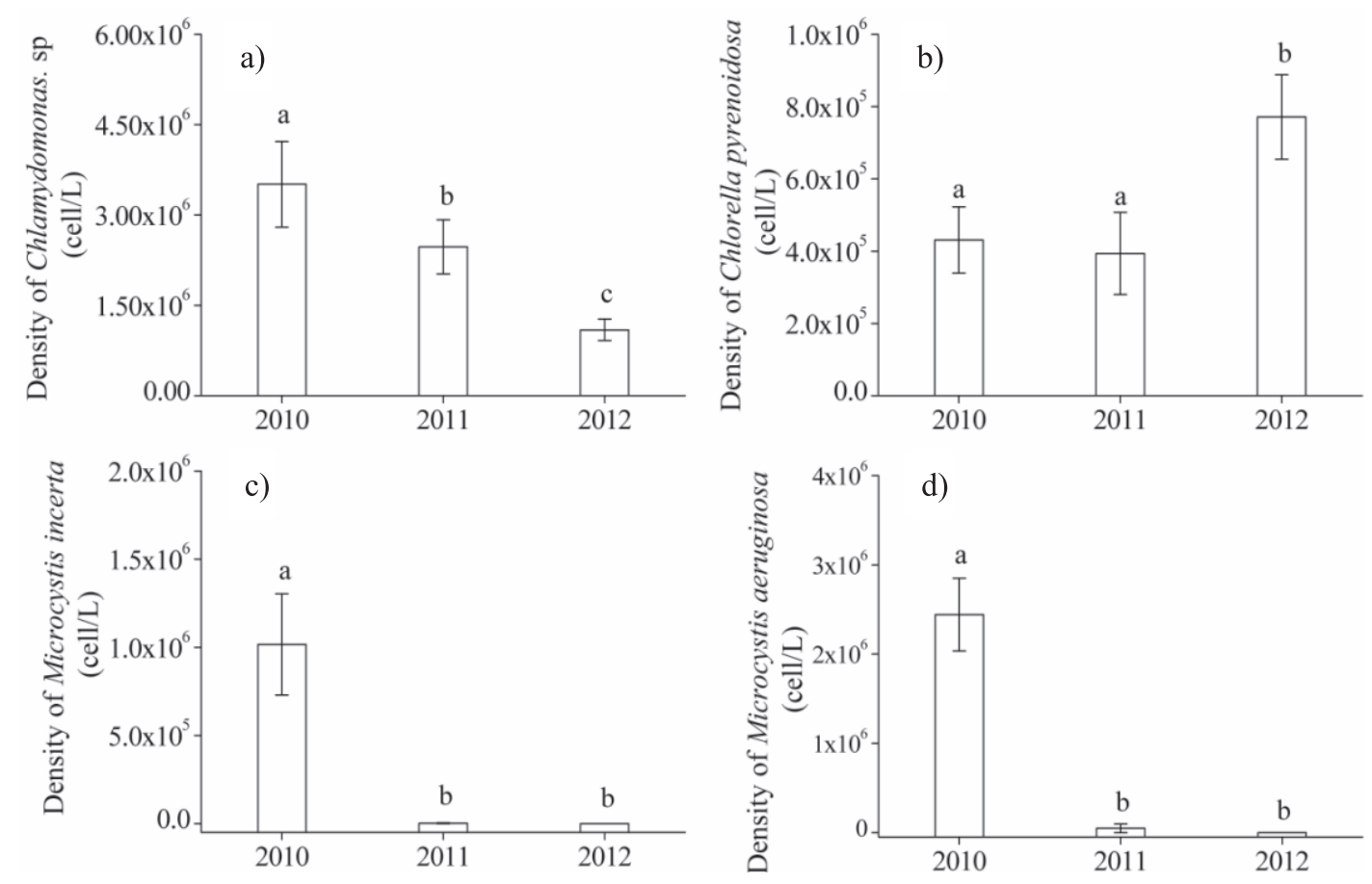

Fig. 5. Interannual mean changes $( \pm \mathrm{SE})$ in phytoplankton-dominant species (Chlamydomonas sp., Chlorella pyrenoidosa, Microcystis incerta, and Microcystis aeruginosa) during the restoration $(\mathrm{N}=27)$.

and COD $(\mathrm{r}=0.54, P<0.01)$, and chlorophyta and TN $(\mathrm{r}=0.81, P<0.01)$, respectively. However, there were no significant relations between species richness and all environmental factors during the restoration.

Some significant relations also occurred between environmental factors (Table 1). Macrophyte coverage and biomass were negatively correlated with COD $\left(\mathrm{r}_{\mathrm{MC}}=-0.57, P<0.01 ; \mathrm{r}_{\mathrm{MB}}=-0.69, P<0.01\right)$ and $\mathrm{TN}$ $\left(\mathrm{r}_{\mathrm{MC}}=-0.78, P<0.01 ; \mathrm{r}_{\mathrm{MB}}=-0.77, P<0.01\right)$, but $\mathrm{TN}$ was positively correlated with $\operatorname{COD}(\mathrm{r}=0.43, P<0.05)$.

\section{Discussion}

\section{Effects of Macrophyte Restoration on Phytoplankton Communities}

In the present study, the density and biomass of total phytoplankton after macrophyte restoration in 2012 was less than those before the restoration in 2010. Combined with the positive correlations between total phytoplankton and nutrients (COD and TN), it might be inferred that nutrients were the main limiting factor of phytoplankton growth. Moreover, the significantly negative correlation between macrophytes and nutrients showed that macrophyte restoration might decrease the limiting nutrients for phytoplankton growth, and indirectly inhibit phytoplankton. This inference was also basically consistent with the conclusions of some studies [31-32].

A very important mechanism is that macrophytes can decrease nutrient loading in a water column by stabilizing substrate to decrease the release of nutrients in sediment.
In West Lake, which is often affected annually by typhoons from the East China Sea, sediment disturbance caused by wind wave accelerates nutrient release. Moreover, boats ferrying across the lake every day can also make the sediment unstable, and promote the release effect. Yet reconstructed macrophytes could effectively reduce wave energies, protect the sediment away from erosion and resuspension, promote sediment sedimentation [33-34], and then decrease the release effect. Therefore, macrophyte restoration might indirectly inhibit phytoplankton growth through the bottom-top control of phytoplankton by decreasing the limiting nutrients.

Moreover, the increasing top-down predation pressure of predators (such as large zooplankton, etc.) on phytoplankton caused by restored macrophytes might also play a crucial role in decreasing phytoplankton in this lake. Many studies in temperate lakes found that submerged macrophytes could provide great refuges for large zooplankton against fish predation [35-36], and then decrease phytoplankton by the top-down control of phytoplankton by large zooplankton [37]. For example, Cazzanelli et al. [38] stated that dense macrophytes in the littoral with a low predation risk might enhance crustacean survival. Burks et al. [39] also suggested that crustaceans could take full advantage of the barrier function of macrophytes in the littoral to escape predation when a high risk of predation existed in the open water during the daytime. Moreover, a survey about fish in March 2012 showed that the fish community was dominated by large carnivorous and omnivorous species (such as Channa argus, Mylopharyngodon piceus, Cyprinus carpio, etc.) [Zeng, unpublished data]. The lack of zooplanktivorous 
fish probablly caused by piscivorous fish might also decrease the predation pressure on large zooplankton, and then strengthen the top-down control of phytoplankton by large zooplankton [40].

In addition, macrophytes might also directly inhibit phytoplankton by the allelopathy of submerged macrophytes [41]. However, allelopathic inhibition of submerged macrophytes on phytoplankton is controversial from the in-situ study point of view, and very little research has reported the existence of in-situ allelopathy of macrophytes [42]. Even so, these direct allelopathic inhibitions from macrophytes might also exist in this study. Because the restored species (V. spiralis, P. crispus, $C$. demersum, and $M$. verticillatum) in our study showed their own strong inhibitions on phytoplankton, according to the range of allelopathy of submerged macrophytes reported by Mulderij [43]. Together with extremely high macrophyte biomass and coverage after the restoration, direct inhibition of macrophytes on phytoplankton growth was very likely to be an important cause in decreasing phytoplankton in our study.

\section{Effects of Macrophyte Restoration on Community Structure}

In this study, the phytoplankton community structure exhibited a great change during the restoration. The significantly positive relationships between COD and cyanobacteria, and chlorophyta and $\mathrm{TN}$ indicated that decreased nutrients might be the main cause for the changes in the phytoplankton community structure. Combined with the significantly negative correlations between macrophytes and nutrients (COD and TN ), it might be inferred that restored macrophytes could indirectly shift the phytoplankton community structure by decreasing the nutrients.

Moreover, the effects of biotic factors on phytoplankton community structure, such as interspecies competition and aquatic macrophytes, are also remarkable [44]. Numerous studies have shown that cyanobacteria could directly affect other species growth by releasing allelopathic substances [45-46]. In this study, the significant reduction in cyanobacteria during the restoration might relieve the interspecies competition between cyanobacteria and other species, and promote their growth to some extent, and thus the ratio of other species in phytoplankton could significantly increase after restoration. In addition, restored macrophytes in this study were very likely to exhibit direct allelopathic inhibitions on cyanobacteria and chlorophyta, and then shift phytoplankton community structure. This inference has also been confirmed by numerous studies. For example, Švanys [47] reported that cyanobacteria and chlorophyta were significantly inhibited by the allelochemicals released from $M$. spicatum. Wang [48] also found that volatile organic compounds as major allelochemicals from Potamogeton cristatus, P. maackianus, P. lucens, V. spinulosa, Ceratophyllum demersum, and Hydrilla verticillata exhibited a significant anti-cyanobacterial activity.
Although restored macrophytes could significantly decrease chlorophyta density, it was still at a high level compared to cyanobacteria after the restoration in 2012, indicating that the tolerance of chlorophyta on the inhibitions from macrophytes was stronger than cyanobacteria. Some studies also supported this conclusion [49]. For example, Jiang [32] found that $H$. verticillata might inhibit the growth of cyanobacteria while showing little effect on the growth of chlorophyta. Švanys [47] also observed that the presence of M. spicatum could only exhibit short-term inhibitions on chlorophyta compared to the long-term inhibitions on cyanobacteria biomass. However, Pełechata and Pełechaty [50] also reported that there was no clear effect of C. demersum stand on cyanobacteria, whereas the decreases in the quantity of cryptophyta, dinophyta, chlorophyta, and chrysophyceae were noted. Therefore, different macrophyte species might exhibit various effects on different phytoplankton groups. In this study, a compound macrophyte community including $V$. spiralis, $N$. marina, and M. Verticillatum, might show stronger inhibitions on cyanobacteria compared to chlorophyta.

\section{Effects of Macrophyte Restoration on Dominant Species}

In this study, significant negative correlations between macrophyte and cyanobacteria density and the significant decreases in densities of two dominant species ( $M$. aeruginosa and $M$. incerta) during the restoration indicated that restored macrophytes might inhibit $M$. sp growth, and then decrease the risk of cyanobacteria blooms. Numerous studies also demonstrated that many macrophytes could significantly suppress some cyanobacteria species [49]. For example, $M$. aeruginosa, as one of the widely known harmful species [51], was found to be inhibited by $H$. verticillata [32]. Dong [52] also reported that the existence of $\mathrm{C}$. demersum could lower the growth of $M$. aeruginosa.

Although restored macrophytes also significantly decreased chlorophyta density, two dominant species (Chlamydomonas sp. and C. pyrenoidosa) exhibited different sensitivities to the inhibitions from macrophytes. That is, $C$. sp. was significantly inhibited, whereas $C$. pyrenoidosa was promoted to some extent. The inhibitions on $C$. sp. might be caused by many factors, such as direct allelopathic effects, indirect control of nutrients, etc. However, increased C. pyrenoidosa was very likely to be related to the decreased interspecies competition between $C$. pyrenoidosa and other dominant species such as M. aeruginosa and M. incerta. Some studies found that cyanobacteria could inhibit the growths of some chlorophyta by releasing the allelochemicals [53-54]. The growth of $C$. pyrenoidosa significantly decreased under the allelopathical effects of linoleic and linolenic acids from M. aeruginosa [55]. Thus, the significant decrease or even disappearance of cyanobacteria after the restoration might decrease the interspecies competition between cyanobacteria and C. pyrenoidosa, and then indirectly promoted the growth of C. pyrenoidosa. 


\section{Conclusions}

In this study, our hypothesis that macrophyte restoration can also significantly decrease phytoplankton and cause changes in community structure in a subtropical eutrophic shallow lake was verified. During the restoration, the density and biomass of total phytoplankton significantly decreased, and both cyanobacteria and chlorophyta were also significantly inhibited, but the tolerances of chlorophyta on the inhibitions from macrophytes were stronger than cyanobacteria. Moreover, the changes in four dominant species were also different. Specifically, Microcystis aeruginosa, $M$. incerta, and Chlamydomonas sp. decreased, but Chlorella pyrenoidosa increased. In addition, the significant correlations between phytoplankton and environmental factors (macrophyte and nutrients) indicated that macrophyte restoration might not only directly inhibit phytoplankton growth, but also indirectly decrease phytoplankton through a bottomup control of phytoplankton by decreasing the limiting nutrients and a top-down control by strengthening predator predation. Therefore, macrophyte restoration, as a potential and useful method to inhibit phytoplankton growth and decrease alga blooms, deserves a wider range of research and attention in future lake management.

\section{Acknowledgements}

This study was supported by the Major Science and Technology Program for Water Pollution Control and Treatment of China's 12 $2^{\text {th }}$ Five-Year Plan (No. 2012ZX07101007-005) and the National Natural Science Foundation of China (Nos. 51178452, 51208498, and 51308530). We would like to thank Prof. Dongru Qiu and Dr. Yafen Wang for their valuable comments and advice. Thanks are also given to other laboratory colleagues for field and laboratory work assistance.

\section{References}

1. ANSARI ABID A., GILL S.S., KHAN F.A. Eutrophication: Threat to Aquatic Ecosystems. Eutrophication: causes, consequences and control. 143, 2010.

2. WATSON S.B., MILLER C., ARHONDITSIS G., BOYER G.L., CARMICHAEL W., CHARLTON M.N., CONFESOR R., DEPEW D.C., HÖÖK T.O., LUDSIN S.A., MATISOFF G., MCELMURRY S.P., MURRAY M.W., PETER RICHARDS R., RAO Y.R., STEFFEN M.M., WILHELM. S.W. The re-eutrophication of Lake Erie: harmful algal blooms and hypoxia. Harmful Algae. 56, 44, 2016.

3. PAERL H.W., HALL N.S., CALANDRINO E.S. Controlling harmful cyanobacteria bloomss in a world experiencing anthropogenic and climatic-induced change. Sci. Total. Environ. 409, 1739, 2011.

4. WATERS M.N., SCHELSKE C.L., BRENNER M. Cyanobacteria dynamics in shallow Lake Apopka (Florida, U.S.A.) before and after the shift from a macrophytedominated to a phytoplankton-dominated state. Freshwater Biol. 60, 1571, 2015.
5. ĐORĐEVIĆ N.B., SIMIĆ S.B. Cyanobacterial blooms in oligosaline and alkaline microaccumulation before and after rehabilitation. Pol. J. Environ. Stud. 23 (6), 1975, 2014.

6. CHEN J., XIE P., LI L., XU J. First identification of the hepatotoxic microcystins in the serum of achronically exposed human population together with indication of hepatocellular damage. Toxicol. Sci. 108, 81, 2009.

7. XIE P. Historical Development of Cyanobacteria with Blooms Fisaster in Lake Taihu. Science Press, Beijing. 2008.

8. KOZAK A., GOLDYN R. Variation in Phyto- and Zooplankton of Restored Lake Uzarzewskie. Pol. J. Environ. Stud. 23 (4), 1201, 2014.

9. ARAÚJO F, BECKER V, ATTAYDE J.L. Shallow lake restoration and water quality management by the combined effects of polyaluminium chloride addition and benthivorous fish removal: a field mesocosm experiment. Hydrobiologia. $1,2015$.

10. YU J., LIU Z., HE H., ZHEN W., GUAN B.H., CHEN F.Z., LI K.Y., ZHONG P., DE MELLO F.T., JEPPSEN E. Submerged macrophytes facilitate dominance of omnivorous fish in a subtropical shallow lake: implications for lake restoration. Hydrobiologia. 1, 2016.

11. COOKE G.D., WELCH E.B., PETERSON S.A., NICHOLAS S.A. Restoration andManagement of Lakes and Reservoirs. CRC Press, Boca Raton, Florida, 2005.

12. JEPPESEN E., MEHNER T., WINFIELD I.J., KANGUR K., SARVALA J., GERDEAUX D., RASK M., MALMQUIST H.J., HOLMGREN K., VOLTA P., ROMO S., ECKMANN R., SANDSTRÖM A., BLANCO S., KANGUR A., STABO H.R., TARVAINEN M., VENTELÄ A.M., SØNDERGAARD M., LAURIDSEN T.L., MEERHOFF M. Impacts of climate warming on the long-term dynamics of key fish species in 24 European lakes. Hydrobiologia. 694, 1, 2012.

13. SAYER C.D., DAVIDSON T.A., RAWCLIFFR R., LANGDON P.G., LEAVITT P.R., COCKERTON G., ROSE N.L., GROFT T. Consequences of fish kills for long-term trophic structure in shallow lakes: implications for theory and restoration. Ecosystems. 1, 2016.

14. LAZZARO X., STARLING F. Using biomanipulation to control eutrophication in a shallow tropical urban reservoir (Lago Paranoá, Brazil). In: Reddy, M.V. (Ed.), Restoration and Management of Tropical Eutrophic Lakes. Oxford \& IBH Publ. Co. Pvt. Ltd., New Delhi and Science Publishers Inc., New Hampshire, 361, 2005.

15. SKOV C., NILSSON P.A. Evaluating stocking of YOY pike Esox lucius as a tool in the restoration of shallow lakes. Freshwater Biol. 52, 1834, 2007.

16. GULATI R.D., PIRES L.M.D., VAN DONK E. Lake restoration studies: failures, bottlenecks and prospects of new ecotechnological measures. Limnologica. 38, 233, 2008.

17. ONSEM S.V., BACKER S.D., TRIEST L. Microhabitatzooplankton relationship in extensive macrophyte vegetations of eutrophic clear-water ponds. Hydrobiologia. 656 (1), 67, 2010.

18. VANDERSTUKKEN M., DECLERCK S.A.J., DECAESTECKER E., MUYLAERT K. Long-term allelopathic control of phytoplankton by the submerged macrophyte Elodea nuttallii. Freshwater Biol. 59 (5), 930, 2014.

19. PAICE R.L., CHAMBERS J.M., ROBSON B.J. Outcomes of submerged macrophyte restoration in a shallow impounded, eutrophic river. Hydrobiologia. 1, 2015. 
20. MUYLAERT K., DECLERCK S., VAN WICHELEN J., DE MEESTER L., VYVERMAN W. An evaluation of the role of daphnids in controlling phytoplankton biomass in clear water versus turbid shallow lakes. Limnologica. 36, 69, 2006.

21. VANDERSTUKKEN M., MAZZEO N., COLEN W.V., DECLERCK S.A.J., MUYLAERT K. Biological control of phytoplankton by the subtropical submerged macrophytes Egeria densa and Potamogeton illinoensis: a mesocosm study. Freshwater Biol. 56, 1837, 2011.

22. JEPPESEN E., MEERHOFF M., JACOBSEN B.A., HANSEN R.S., SØNDERGAARD M., JENSEN J.P., LAURIDSEN T.L., MAZZEO N., BRANCO C.W.C. Restoration of shallow lakes by nutrient control and biomanipulation-the successful strategy varies with lake size and climate. Hydrobiologia. 581, 269, 2007.

23. LOVERDE-OLIVEIRA S.M., HUSZAR V.L.M., MAZZEO N., SCHEFFER M. Hydrology-driven regime shifts in a shallow tropical lake. Ecosystems. 12, 807, 2009.

24. BACHMANN R.W., HORSBURGH C.A., HOYER M.V., MATARAZA L.K., CANFIELD D.E. Relations between trophic state indicators and plant biomass in Florida lakes. Hydrobiologia. 470, 219, 2002.

25. FERNANDEZ-ALAEZ M., FERNANDEZ-ALAEZ C., BECARES E., VALENTIN M., GOMA J., CASTRILLO P. A 2-year experimental study on nutrient and predator influences on food web constituents in a shallow lake of north-west Spain. Freshwater Biol. 49, 1574, 2004.

26. KOSTEN S., LACEROT G., JEPPESEN E, MARQUES D.D., VAN NES E.H., MAZZEO N., SCHEFFER M. Effects of submerged vegetation on water clarity across climates. Ecosystems. 12, 1117, 2009.

27. MUYLAERT K., PEREZ-MARTINEZ C., SANCHEZCASTILLO P., LAURIDSEN T.L., VANDERSTUKKEN M., DECLERCK S.A.J., VAN DER GUCHT K., CONDEPORCUNA J.M., JEPPESEN E., MEESTER L.D., VYVERMAN W. Influence of nutrients, submerged macrophytes and zooplankton grazing on phytoplankton biomass and diversity along a latitudinal gradient in Europe. Hydrobiologia. 653, 79, 2010.

28. ZHOU Q.X., GIBSON C.E., ZHU Y. 2001. Evaluation of phosphorus bioavailability in sediments of three contrasting lakes in China and the UK. Chemosphere. 42 (2), 221, 2001.

29. STATE EPA of CHINA (Ed.). Monitoring and Determination Methods for Water and Wastewater, $4^{\text {th }}$ ed. China Environmental Science Press, Beijing, 836, 2002.

30. HU H.J., WEI Y.X. THE FRESHWATER ALGAE OF CHINA: Systematics, Taxonomy and Ecology. Science Press, Beijing. 2006.

31. CIURLI A., ZUCCARINI P., ALPI A. Growth and nutrient absorption of two submerged aquatic macrophytes in mesocosms, for reinsertion in a eutrophicated shallow lake, Wetl. Ecol. Manag. 17, 107, 2009.

32. JIANG H., ZHAO D., ZHAO H., CAI Y., XU D.L., ZHOU C.F., LENG X., XIE D. Density-Dependent Interactions Between Hydrilla verticillata, (L.F.) Royle and Phytoplankton: A Mesocosm Experiment. Clean Soil Air Water 43, 1623, 2015.

33. LI E.H., LI W., LIU G.H., YUAN L.Y. The effect of different submerged macrophyte species and biomass on sediment resuspension in a shallow freshwater lake. Aquat. Bot. 8 (2), 121, 2008.

34. ZHU M., ZHU G., NURMINEN L., WU T., DENG J., ZHANG Y., QIN B., VENTELÄ A. The influence of macrophytes on sediment resuspension and the effect of associated nutrients in a shallow and large lake (lake taihu, china). Plos One. 10 (6), 2015.

35. ŠPOLJAR M., DRAŽINA T., HABDIJA I., MESELJEVIĆ M., GRČIĆ Z. Contrasting zooplankton assemblages in two oxbow lakes with low transparencies and narrow emergent macrophyte belts (Krapina River, Croatia). Int. Rev. Hydrobiol. 96, 175-190, 2011.

36. ŠPOLJAR M., TOMLJANVIĆ T., DRAŽINA T., LAJTNER J., ŠTULEC H., MATULIĆ D. Zooplankton structure in two interconnected ponds: similarities and differences. Journal of Fisheries. 74, 6, 2016.

37. JEPPESEN E., JENSEN J.P., SØNDERGAARD M., LAURIDSEN T., PEDERSEN L.J., JENSEN L. Topdown control in freshwater lakes: the role of nutrient state, submerged macrophytes and water depth. Hydrobiologia. 342-343, 151-164, 1997.

38. CAZZANELLI M., WARMING T.P., CHRISTOFFERSEN K.S. Emergent and floating-leaved macrophytes as refuge for zooplankton in a eutrophic temperate lake without submerged vegetation. Hydrobiologia. 605, 113, 2008.

39. BURKS R.L., LODGE D.L., JEPPESEN E., LAURIDSEN T.L. Diel horizontal migration of zooplankton: cost and benefits of inhabiting the littoral. Freshwater Biol. 47, 343, 2002.

40. BLINDOW I., HARGEBY A., HILT S. Facilitation of clear-water conditions in shallow lakes by macrophytes: differences between charophyte and angiosperm dominance. Hydrobiologia. 737, 99, 2014.

41. WANG H.Q., CHENG S.P., ZHANG S.H., HE F., LIANG W., ZHANG L.P., HU C.Y., GE F.J., WU Z.B. Chemical composition in aqueous extracts of Potamogeton malaianus and Potamogeton maackianus and their allelopathic effects on microcystis aeruginosa. Pol. J. Environ. Stud. 19 (1), 213, 2010.

42. MJELDE M., FAAFENG B.A. Ceratophyllum demersum hampers phytoplankton development in some small Norwegian lakes over a wide range of phosphorus concentrations and geographical latitude. Freshwater Biol. 37, 355, 1997.

43. MULDERIJ G., SMOLDERS A.J.P., VAN DONK E. The allelopathic effect of Stratiotes aloides on phytoplankton under natural conditions. Freshwater Biol. 51, 554, 2006.

44. JIN X., JING J., SHENG L., JIN M. Interspecies competition between Microcystis aeruginosa and Scenedesmus obliquus under phenanthrene stress. Pol. J. Environ. Stud. 23 (5), 1609, 2014.

45. SUIKKANEN S., FISTAROL G.O., GRANÉLI E. Allelopathic effects of the Baltic cyanobacteria Nodularia spumdigena, Aphanizomenon flos-aquae, and Anabaena lemmermannii on algal monocultures. J. Exp. Mar. Biol. Ecol. 308 (1), 85, 2013.

46. NAHA S., BISWAS N., GODHANTARAMAN R.K., SARANGI B.D., BHATTACHARYA S.K., SARKAR, SATPATHY K.K. Blooms of Hemidiscus hardmannianus (Bacillariophyceae) and Its Impact on Water Quality and Plankton Community Structure in a Mangrove Wetland. Clean Soil Air Water. 41, 333, 2013.

47. ŠVANYS A., PAŠKAUSKAS R., HILT S. Effects of the allelopathically active macrophyte Myriophyllum spicatum on a natural phytoplankton community: a mesocosm study. Hydrobiologia. 737, 57, 2014.

48. WANG H., LIANG F., ZHANG L. Composition and AntiCyanobacterial Activity of Essential Oils from Six Different Submerged Macrophytes. Pol. J. Environ. Stud. 24 (1), 333, 2015. 
49. HILT S., GROSS E.M. Can allelopathically active submerged macrophytes stabilize clear-water states in shallow lakes? Basic Appl. Ecol. 9, 422, 2008.

50. PEŁECHATA A., PEŁECHATY M. The in situ influence of Ceratophyllum demersum on a phytoplankton assemblage. Oceanol. Hydrobiol. St. 39 (1), 95, 2010.

51. FIGUEIRDO DE D.R., AZEITEIRO U.M., ESTEVES S.M., GONC ALVES F.J.M., PEREIRA M.J. Microcystinproducing bloomss-a serious global public health issue. Ecotox. Environ. Safe. 59, 151, 2004.

52. DONG J., YANG K., LI S., LI G., SONG L. Submerged vegetation removal promotes shift of dominant phytoplankton functional groups in a eutrophic lake. J. Environ. Sci. 26, 1699, 2014
53. GRANELI E., WEBERG M., SALOMON P.S. Harmful algal bloomss of allelopathic microalgal species: the role of eutrophication. Harmful Algae. 8, 94, 2008.

54. CHANG X., EIGEMANN F., HILT S. Do macrophytes support harmful cyanobacteria? Interactions with a green alga reverse the inhibiting effects of macrophyte allelochemicals on Microcystis aeruginosa. Harmful Algae. 19, 76, 2012.

55. ZHANG M., KONG F., XING P., TAN X. Effects of interspecific interactions between Microcystis aeruginosa, and Chlorella pyrenoidosa, on their growth and physiology. Internat. Rev. Hydrobiol. 92 (3), 281, 2007. 
